\title{
Environmental management in the Port of Koper and neighboring urban settlements
}

\author{
O. Bajt ${ }^{1}$, I. Jurincic ${ }^{2}$ \& B. Marzi ${ }^{3}$ \\ ${ }^{1}$ Marine Biology Station Piran, National Institute of Biology, Slovenia \\ ${ }^{2}$ TURISTICA - College of Tourism Portoroz, University of Primorska, \\ Slovenia \\ ${ }^{3}$ Port of Koper, Slovenia
}

\begin{abstract}
Service quality and appropriate environmental management in the Port of Koper are a constant concern for the administration. The port is located at the northern and eastern borders of the town of Koper, therefore, the administration has always paid careful attention to limiting and controlling its potentially negative environmental impacts. All its spatial interventions have therefore been subject to thorough spatial and environmental assessment. The withdrawal of some potentially inappropriate projects in the history of the Port was an obvious result of detailed assessments. During the preparation of the development and spatial plans, significant corrections and moderating measures were introduced in the majority of the proposed projects due to the port's location close to the urban environment. Permanent environmental monitoring of noise, air and water in the Bay of Koper was also introduced during the investments of the past twenty years, which made auditing of the Port's impacts on the environment possible.

Keywords: environmental management, Port of Koper, ISO 14001/2004, environmental impacts, spatial planning, monitoring.
\end{abstract}

\section{Introduction}

The Port of Koper is located in close proximity of urban areas and for that reason a concern for appropriate environmental management has always been present in the administration of the port. To ensure the safety of the environment, a number of measures have been taken according to independent environmental studies. A 
special investment service was founded in the beginning for the inspection and execution of these measures, and an environmental manager was named in 2004 in compliance with the environmental protection law.

Pretentious urban planning of the port has always been carried out in tight cooperation of the administration with local and government authorities. Reasons for such a method lie in the very foundation of the company. In the beginning, it was a huge government project which resulted in a rise of employment in the area. Soon the rapid growth of the port called for effective spatial planning measures. These were supervised by those competent for development and spatial growth. The port itself is now bigger than it's nearest neighboring town, Koper where it has been located by since 1957. It has tremendous economic value of which a major portion is still owned by the government. Yet an important part is also the property of the community of Koper.

The Port of Koper is run in connection with the marine traffic corridor and is one of the entry points of the fifth pan-European corridor. It therefore exceeds the significance of Koper, Primorska region or Slovenia. European documents encourage the stimulation of intermodal transport chains where seaports are very significant and have a key role. The Port of Koper is a link between the marine traffic corridor and the fifth pan-European corridor and thereby the largest intermodal junction in Slovenia. A consistent growth of the commercial Port of Koper is crucial as more and more merchandise is transported by marine-traffic.

The governmental concern for the only commercial port can be seen in the careful monitoring programs of the Slovene sea. This has been executed by an independent organization National institute of biology - Marine biology station Piran.

\section{Spatial planning of the Port of Koper in the past}

By reviewing the history of spatial planning in the area of the port it is clearly seen that the local community shows a high responsibility for economic development of the port in accordance with spatial possibilities. Its effects on environment must not exceed the limits dictated by law, nor can they have a long-term impact on natural resources. Every major development of the port area has been the subject of careful evaluation involving thorough study of possible negative effects on the surrounding areas and their inhabitants [1].

In the 1970s there was proposed an intensive economic development in the port. It was a mega industrial project which envisaged cheaper import and export of power supplies, ironworks, thermal power stations and other manufacturing industry at the port. This project, however, was terminated. It was decided that such an industrial development would exploit the advantages of a location close to the supply of resources, and would be a threat to the environment.

Similarly, a project in the 1980s, the off-loading of oil derivatives, suffered a similar fate. Its location was outside the port's borders on the Debeli rtic peninsula which lies between Koper and Trieste. In addition, it could have had a potentially huge negative environmental impact on the surrounding area in the case of an accident. It was taken into consideration that the peninsula is the most 
preserved coastal and tourist region of the Slovenian sea. After a broad public discussion, the great flysch cliff region was declared a natural monument and thereby the oil terminal project ultimately rejected.

The unloading and storage of liquid petroleum gas (LPG) in the 1990s hit upon disapproval by local habitants as well. Despite good results from environmental studies, proving a very small potential for disasters, the port had to withdraw the project under public pressure.

A number of planned projects have also been partially or substantially modified due to the close proximity of urban areas. The question of environmental impact has often been the major determinant of these decisions. A terminal for unloading scattered cargo in 1980s was reduced by half. The constant moistening of the dumping ground was also introduced. At the same time the port began regular monitoring of the European energy terminal (EET) and its effects on the environment. The monitoring led to other modifications as well. At first a green curtain had been installed to reduce micro-particles in the air. This was later improved by raising a high enclosure that provides much better results.

\section{Environmental impact of the Port of Koper}

For one year, April 18, 2005 to April 19, 2006 a constant recording of total concentrations of inhalable dust particles PM10 was enforced in the immediate vicinity of the European energy terminal. This was executed by University of Primorska - Primorska Institute of Natural Sciences and Technology.

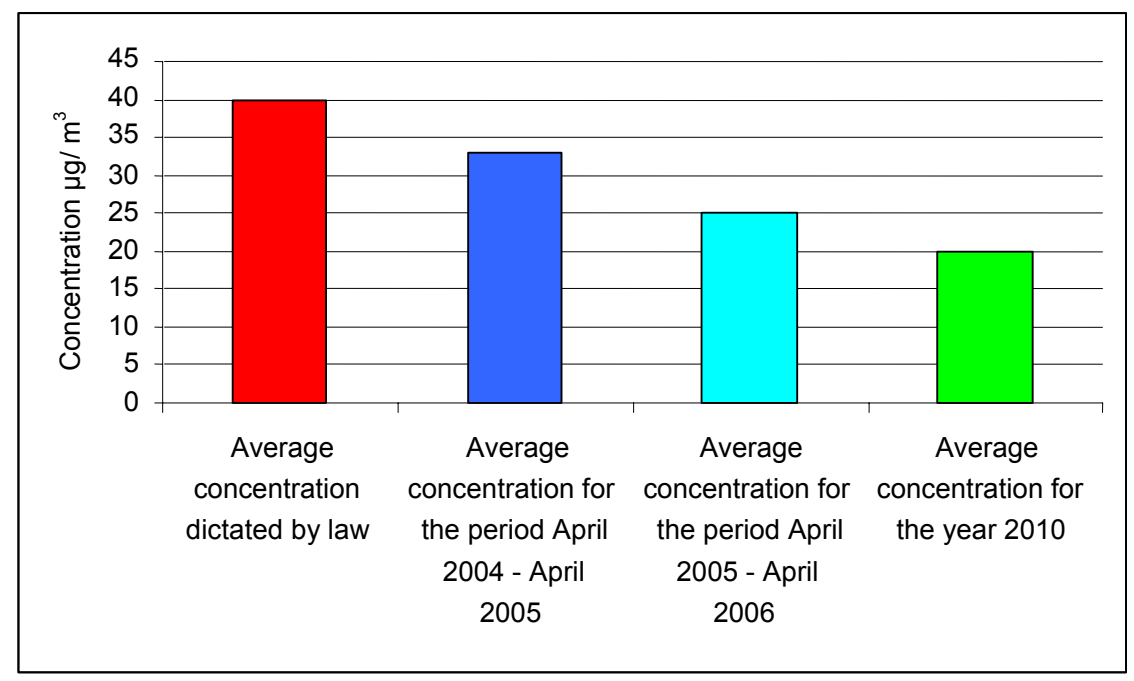

Figure 1: Concentration of dust particles PM10.

By EU guidelines the highest permitted concentration of dust in the air is 40 $\mu \mathrm{g} / \mathrm{m}^{3}$ [2]. According to previously mentioned recordings the concentration of 
dust particles PM10 in the port was PM10 25,1 $\mu \mathrm{g} / \mathrm{m}^{3}$. In comparison to the average concentration recorded a year before, the recorded value was reduced by about $23 \%$. It is important to note that off-loading activities actually increased during this period of time.

In accordance with the EU Environmental Code of Practice for seaports, namely co-existence of the port with the environment, and increasingly lower limit for concentration levels of individual elements in dust particles, lesser than $10 \mu \mathrm{m}$ in size, the port has invested in environment-friendly equipment. Thus, by setting up fences that protect neighboring settlements from dust and noise, the port has also improved its visual appearance.

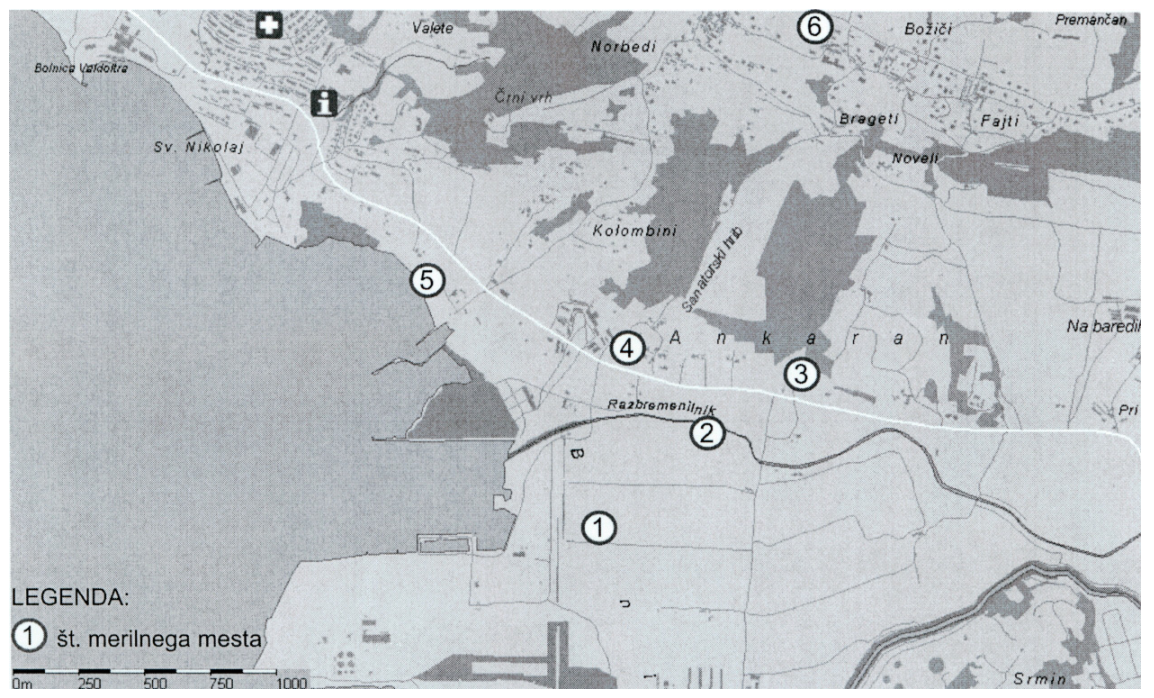

Figure 2: $\quad$ Measuring points for air pollution by dust sediments.

In October 2005 a project was initiated with the objective of constant development to ensure higher environmental responsibility and to introduce a system of environmental regulation to a wider area. The project is called "Inspection of air pollution by dust sediments in the area of local communities Ankaran and Hrvatini". It includes yearly analysis of assessments from the regions impacted by dust particles. This takes into account the wind and distance from the iron-ore and coal dumping grounds at the EET region. Samples are taken from six points (figure 2), from which the measuring point 6 is a checkpoint used for comparison between dust concentration from direction of Trieste and of Koper. The results will be known by the end of the year 2006 .

\section{Impact of the Port of Koper on the sea}

Bay of Koper is a part of Gulf of Trieste (north Adriatic Sea), on its south-east section. It is a rather shallow bay with its maximum depth below $20 \mathrm{~m}$. Its water- 
mass circulation is complex and depends upon various factors, such as tide, winds and influx of freshwater from the land. There are two freshwater rivers flowing into the bay of Koper, namely river Rizana and river Badasevica. River Rizana is somewhat bigger and has its outlet at the port's area. These two rivers supply the bay of Koper with a significant amount of nutrients (eutrophication processes). They also contain some pollutants such as heavy metals, pesticides and hydrocarbons. An important potential source of pollution is the city of Koper with its sewage treatment plant (only the primary step of purification) and waters released into river Rizana just before it flows into the sea, as well as its pollution of the atmosphere. There is also a coastal road between Koper and Izola at the south section of the bay. This road is highly traveled, especially in the summer, with the influx of tourists. The runoff from this road is washed away directly into the waters of the bay of Koper.

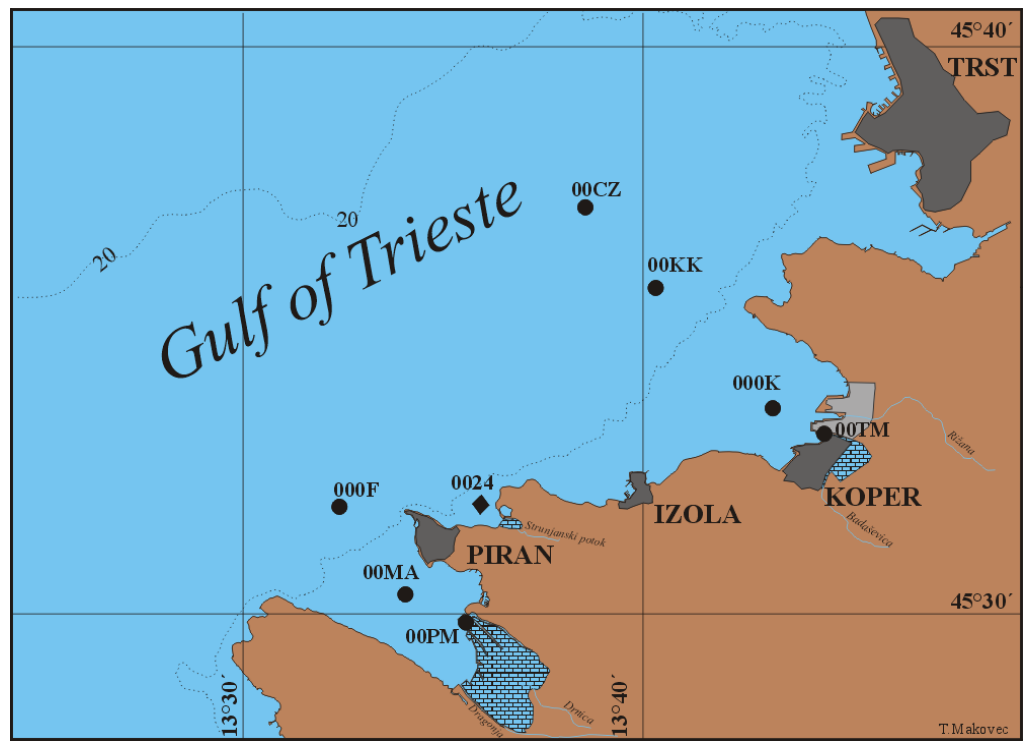

Figure 3: Sampling sites for monitoring of the quality of Slovenian sea.

The quality of Slovenian sea is constantly being monitored by the Republic of Slovenia [3]. Main sampling sites are shown in figure 3, but samples of water, sediments and marine organism are taken elsewhere as well. It varies depending on the specific purposes of the sampling.

The appointed parameters are mostly basic physical-chemical parameters (temperature, salinity, density, $\mathrm{pH}$, alkalinity, nutrients...) and some specific pollutants, chosen according to the expected origins of input (heavy metals, hydrocarbons, pesticides).

The impact of the Port of Koper on the sea is most evident with the level of hydrocarbons in samples of sediments and certain mussel - Mytilus Galloprovincialis. Sediment samples were taken because hydrocarbons are hydrophobic substances with low solubility in water and they adsorb on 
suspended matter in the sea. In this way they accumulate in sediments. Mussels create a similar effect, as they are filtering organisms which accumulate various pollutants in their tissue. This particular species is quite common in this region and is, therefore, a good indicator organism.

The analyses have been performed according to instructions by UNEP [4, 5]. The level of aliphatic hydrocarbons (C14-C34, Phytane, Pristane) in the sediments is shown in table 1, while the level of polyaromatic hydrocarbons $(\mathrm{PAH})$ in table 2.

Table 1: Content of aliphatic hydrocarbons in sediments of the Bay of Koper (ng/g of dry sediment) in 2003.

\begin{tabular}{|l|c|c|c|c|}
\hline Sampling site & $00 \mathrm{TM}$ & $000 \mathrm{~K}$ & $00 \mathrm{KK}$ & $000 \mathrm{~F}$ \\
\hline Aliphatic hydrocarbons & 9951 & 2149 & 1404 & 956 \\
\hline
\end{tabular}

Table 2: Content of polyaromatic hydrocarbons in sediments of the Bay of Koper (ng/g of dry sediment) in 2003.

\begin{tabular}{|l|c|c|c|c|}
\hline & \multicolumn{4}{|c|}{ SAMPLING SITE } \\
\hline HYDROCARBONS & $00 \mathrm{TM}$ & $000 \mathrm{~K}$ & $00 \mathrm{KK}$ & $000 \mathrm{~F}$ \\
\hline Naphthalene & $<1$ & 9 & $<1$ & $<1$ \\
\hline 1-methyl naphthalene & $<1$ & 3 & $<1$ & $<1$ \\
\hline 1-ethyl naphthalene & $<1$ & $<1$ & $<1$ & $<1$ \\
\hline Acenaphthene & $<1$ & $<1$ & $<1$ & $<1$ \\
\hline Acenaphtylene & $<1$ & $<1$ & $<1$ & $<1$ \\
\hline Phenanthrene & 38 & 38 & 11 & 28 \\
\hline Anthracene & 39 & 20 & 17 & 35 \\
\hline Fluorene & 213 & $<1$ & $<1$ & $<1$ \\
\hline 2-methyl phenanthrene & 12 & 5 & 5 & 5 \\
\hline 1-methyl phenanthrene & 6 & 4 & 4 & 6 \\
\hline Fluoranthene & 41 & 75 & 25 & 46 \\
\hline Pyrene & 47 & 110 & 57 & 57 \\
\hline 3,6-dimethylphenanth. & $<1$ & $<1$ & $<1$ & $<1$ \\
\hline 1-methyl pyrene & $<1$ & $<1$ & $<1$ & $<1$ \\
\hline Perylene & 169 & $<1$ & $<1$ & $<1$ \\
\hline Chrysene & 351 & 74 & 47 & 57 \\
\hline Squalan & $<1$ & $<1$ & $<1$ & $<1$ \\
\hline Benzo(a)anthracene & 54 & 44 & 19 & 30 \\
\hline Benzo(b)fluoranthene & 119 & 93 & 50 & 51 \\
\hline Benzo(k)fluoranthene & 49 & 48 & 25 & 47 \\
\hline Benzo(e)pyrene & 46 & 58 & 47 & 47 \\
\hline Benzo(a)pyrene & 15 & 41 & 23 & 53 \\
\hline Indeno(1,2,3-c,d)pyrene & 103 & 50 & 33 & 55 \\
\hline Dibenzo(a,h)anthraceen & 42 & 17 & 30 & 15 \\
\hline Benzo(g,h,i)perylene & 39 & 77 & 138 & 74 \\
\hline Total & 1383 & 766 & 531 & 606 \\
\hline
\end{tabular}


In both cases we can see a higher level of concentration at the 00TM site which lies at the port's entrance. Concentration level of a site further into the bay is much lower and hardly any higher than the reference site $000 \mathrm{~F}$, located at a more open section of Slovene sea. Regarding the structure of PAHs present, we can conclude that the hydrocarbons are of various origins - a prevailing pyrogenic origin with some smaller amount of the petrogenic origin.

The impact of Port of Koper on marine environment is, as said before, also indicated by results from analyses of mussels which are presented in table 3 . In the case of PAH we can see an increased concentration level in the mussels sampled near the port's entrance (00TM) in comparison to those sampled in the bay of Strunjan (0024, reference site), where there are no significant signs of pollution. The difference is not as noticeable in the case of aliphatic hydrocarbons, which is most likely a result of additional natural inputs of aliphatic hydrocarbons in the sea.

On the basis of presented results, we can clearly see that the activities of the Port of Koper have a definite impact on the pollution of the Bay of Koper, but this impact is relatively limited to the port's vicinity. We can therefore conclude: the marine environment of the Bay of Koper is only moderately polluted with hydrocarbons, as the concentration levels of PAHs in the surroundings of the Port of Trieste are several times higher [6]. It would be necessary, however, to initiate several more analyses of other possible pollutants in the bay of Koper, which may be a product of activities in the Port of Koper.

Table 3: Hydrocarbon level (ng/g dry weight) in Mytilus Galloprovincialis tissue in 2004.

\begin{tabular}{|l|c|c|c|c|}
\hline Sampling site & 0024 & \pm SD & $00 \mathrm{TM}$ & \pm SD \\
\hline Aliphatic hydrocarbons & 2563 & 464 & 3701 & 834 \\
\hline Polyaromatic hydrocarbons & 771 & 183 & 2759 & 303 \\
\hline
\end{tabular}

\section{Planning of new terminals and environmental management}

The Port of Koper knows about the environmental impacts of their activities. That is why their business politics are directed towards a rational management of the environment, to preserve it for the generations to come. Assessment and control of the environmental impacts has therefore become regular practice. The port was among the first in Europe and the very first in the Adriatic Sea to initiate an environmental management system according to ISO 14001 standard for all seaport activities in year 2000. In May of 2006 it was upgraded to ISO $14001 / 2004$. When it comes to regular assessment and control of environmental impacts, the port cooperates with competent professional institutions. The Port of Koper handles the environmental management thoroughly. The fact that the company, Luka Koper d.d., manages the whole port area, enables the protection system to be present at all terminals and at all activities.

A need for new off-loading and storage areas has lately appeared, due to the changes in off-loading structures. Cargo ships are getting constantly bigger, 
hence the demand for accommodation of operative coasts, entire docking infrastructure, and compatible technologies. The goal is to turn the extensive spatial usage to a more intensive or specialized construction and restructuring, which will also solve many ecological questions.

The Port of Koper is situated near a densely populated region - Koper, Ankaran and other settlements in the area. For that reason further development of the port must be carefully planned. Thus taking into consideration the boundaries set by an existing concept of urban development for wider area. It is possible to plan further spatial development of the port in Koper by expanding the existing terminals. The operative coasts of piers I and II can be extended to the west, and a $3^{\text {rd }}$ pier can be constructed. This includes the area between the port and the coast of Ankaran. The port is also planning to build a green line and a water line of separation. In addition, an infrastructure of the passenger terminal in Koper area is going to be improved.

The traffic infrastructure of the Port of Koper is of national importance. The Ministry of Environment and Spatial Planning and the community of Koper are preparing a long-term detailed plan to specify spatial possibilities for economic development of the port. The detailed plan is to determine the borders of the port on its south and especially on its northern end. For this reason, representatives from the bordering communities are to be present at the planning stages (figure 4). The inhabitants of Ankaran, for example, are either opposing the expansion of the port towards their tourist settlement, or demand the $3^{\text {rd }}$ pier's activities not to be aggravating and disturbing. The situation to the south is not as problematic. Some of the valid spatial plans are already being executed, withdrawing some of the fist docks of the port from the north part of city of Koper. After fifty years the north part of Koper is now opened to the sea again, and a bypass that enables circular traffic has been built around the city. The coast cleared by the port will be used for a passenger terminal, a suitable infrastructure.

There are various activities performed throughout the entire rejoin of the port and the impact of their synergy can be quite problematic. In order to best monitor spatial usage, and suitably distribute various activities, the international port of Koper, and its contact points (residential, tourist, administrative areas, and protected zones), must be developed holistically.

The new detailed plan of national importance, now being prepared, envisions a docking infrastructure in accordance with the developmental projects of the Port of Koper. Spatial activity planning is founded on the basis of the existing port's structure, where individual functional complexes are connected with the infrastructure. The plans for functional complexes are [7]: reinstatement of a passenger terminal with suitable infrastructure, expansion and widening the activities on piers I and II by building a new infrastructure and extending the operative coasts, construction of a multipurpose terminal on pier III and development of a new entrance into the port at Srmin.

Bearing in mind the programme, defined by the plan for preparation (based on references from first spatial conference, where representatives from neighboring communities also participated) of spatial analysis, analysis of guidelines (acquired with analysis of spatial conditions, tendencies and 
possibilities), as well as study of vulnerability, the Ministry is putting up a public tender to gain a holistic professional solution regarding urban, landscape, architectural, and constructional-technical needs. To evaluate these solutions, spatial development (rational spatial usage), its functionality, and safety will be taken into consideration. Based on the chosen solution, the planner has to propose and substantiate the best possible variable, direct its optimization, create professional basis, and form a proposition for the detailed plan of national importance.

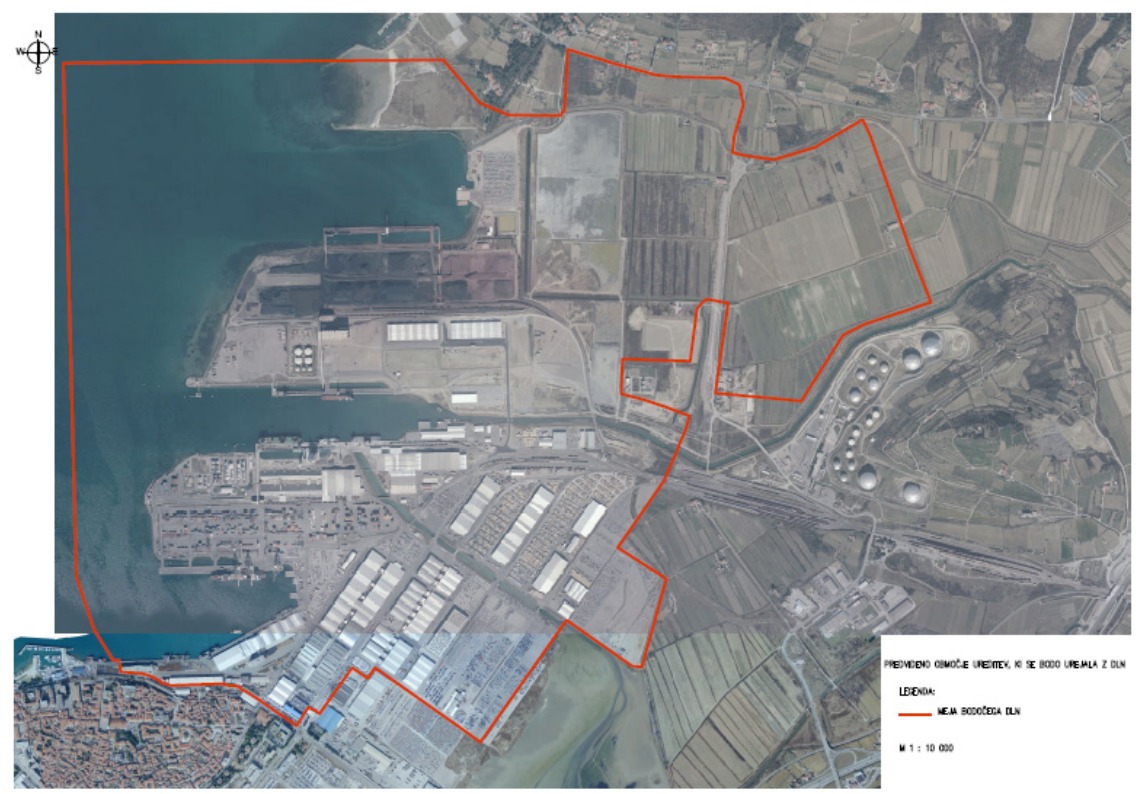

Figure 4: Area of the detailed plan of national importance for the Port of Koper.

\section{Conclusions}

The Port has shown awareness of the advantages and disadvantages brought about by its close proximity to the urban center. In accordance with the EU Environmental Code of Practice for seaports, that is, co-existence of the port with the environment, the port has invested in environment-friendly equipment and appearance, which enhances the contact area of the Port of Koper with the neighbouring settlements and its visual appearance. In spite of the observed impacts of the Port we can still say, however, that the marine environment of the Bay of Koper is only moderately polluted. Due to its need for new development area, the Port has been moving away from Koper and come closer to another urban and tourist settlement, Ankaran. This is also the reason why the latest plans for the construction of a new container terminal are subject to detailed assessment and the local community actively involved in the process. The port 
has to constantly give additional reports to the neighboring inhabitants of current events and plans of any new activities. Public relations need to be widespread such as regular updating of the homepage, forwarding information through local and national media, and opening doors for public visits. Some of the most urgent public questions can be answered by an open and transparent politics of the port.

\section{References}

[1] Jurincic, I. \& Bratoz, D. Koper. In Sarec, A., Sasek-Divjak, M., Mandic, S., Vitorovic, Z., Zavodnik Lamovsek, A. (Ed.). Habitat II: Slovenian national report, pp. 55-78. Ljubljana: Ministry of the Environment and Physical Planning, 1996.

[2] Zitnik, M., Jakomin, M., Pelicon, P., Rupnik, Z., Simcic, J., Budnar, M., Grlj, N., Marzi, B. Port of Koper - elemental concentrations in aerosols by PIXE. X-ray spectrometry 34, pp. 330-334, 2005.

[3] Turk, V., Malej, A., Bajt, O., Mozetic, P., Ramsak, A., Horvat, M., Milacic, R., Scancar, J., Bosnjal, D. National monitoring programme of Slovenia: programme for the assessment and control of pollution in the Mediterranean region (MED POL - PHASE III): report 2004, Reports MBS - Marine Biology Station 70. Piran: National Institute of Biology, Marine Biological Station, 2005.

[4] UNEP/IOC/IAEA. Determination of petroleum hydrocarbons in sediments. Reference Methods for Marine Pollution Studies No. 20, 1992.

[5] UNEP/FAO/IOC/IAEA. Guidelines for monitoring chemical contaminants in the sea using marine organisms. Reference Methods for Marine Pollution Studies No.6, 1993.

[6] Adami, G., Barbieri, P., Piselli, S., Predonzani, S. \& Reisenhofer, E., Detecting and characterising sources of persistent organic pollutants (PAHs and PCBs) in surface sediments of an industrialized area (harbour of Trieste, northern Adriatic Sea). Journal of Environmental Monitoring, 2, pp. 261-265, 2000.

[7] Ministry of Environment and Spatial Planning, Spatial Planning Directorate, www.gov.si/upr/aktualno.php 